\title{
HUBUNGAN PERILAKU SEKSUAL REMAJA SMU DENGAN STATUS PERNIKAHAN ORANG TUA DI KOTA MATARAM NUSA TENGGARA BARAT
}

\author{
Mukminah1, Djauhar Ismail ${ }^{2}$, dan Abdul Wahab ${ }^{3}$ \\ ${ }^{1}$ Fakultas Ilmu Tarbiyah dan Keguruan IAIN Mataram \\ 2Department of Pediatrics, Faculty of Medicine, Gadjah Mada University \\ ${ }^{3}$ Graduate Program of Maternal and Child Health-Reproductive Health, \\ Department of Public Health, Faculty of Medicine, Gadjah Mada University
}

\begin{abstract}
The condition of family life whereby there is divorce or separation will either mentally or psychologically affect children in the family that becomes more obvious as the children grow up. Moreover, when there are other factors that support the behavior. To identify association between sexual behavior of senior high school teenagers and marital status of parents at Mataram Municipality Nusa. Data analysis used chi square $\left(\chi^{2}\right)$ and logistic regression at confidence interval 95\%. Result: Marital status of parents was significantly associated with sexual behavior of teenagers with pvalue 0.0001 and PR 2.03 (CI 95\% 1.65-2.50). The result of bivariate analysis showed significant association between variable of peers' influence with p value 0.0001 and PR 2.40 (CI95\% 1.903.04 ) and variable of mass media exposure with p-value 0.0001 and PR 3.92 (CI 95\% 2.42-6.36) and sexual behavior of teenagers. The result of logistic regression analysis showed marital status of divorced parents had the probability of increasing sexual behavior of teenagers as much as 19\% after being controlled by variables of peers' influence and mass media exposure. Conclusion: Marital status of parents was associated with sexual behavior of teenagers. Teenagers whose parents were divorced had the probability for higher sexual behavior than those whose parents were not divorced.
\end{abstract}

Keywords: sexual behavior, teenagers, marital status, senior high school 


\section{PENDAHULUAN}

Orang tua, baik ayah maupun ibu memegang peranan penting dalam memenuhi kebutuhan fisik dan mental maupun psikis anak mereka.Seorang ayah berperan ganda dalam perkembangan anak, Pertama, sebagai figur atau model dewasa bagi anaknya.Kedua sebagai pendukung dan pelindung yang memperkuat peranan ibu dalam keluarga.

Orang tua sangat berperan dalam hal tumbuh kembang anak, termasuk dalam hal pemahaman tentang seksual. Beberapa hasil penelitian terdahulu menunjukkan bahwa orang tua dapat mengurangi kemungkinan remaja melakukan perilaku seksual berisiko. Parare dan Suris membuktikan bahwa kualitas hubungan antara remaja dan orang tua berpengaruh nyata terhadap perilaku seksual remaja. Remaja-remaja yang memiliki kualitas hubungan baik dengan orang tuanya, lebih terhindar dari perilaku berisiko, yakni lebih sedikit yang pernah melakukan hubungan seksual pertama dan tidak suka berganti-ganti pasangan (multiple partners).

Berdasarkan usia, remaja (adolescence) diartikan sebagai masa perkembangan transisi antara masa anak-anak dan masa dewasa yang mencakup perubahan biologis, kognitif dan sosialemosional. Perilaku seksual merupakan perilaku yang didasari oleh dorongan seksual atau kegiatan untuk mendapatkan kesenangan organ seksual melalui berbagai perilaku. Adapun perilaku ini antara lain: berfantasi, masturbasi, berpengangan tangan, cium pipi, cium bibir dan petting sampai intercourse.

Kualitas pernikahan orang tua berpengaruh signifikan terhadap perilaku seksual remaja.Kondisi serupa juga berpotensi terjadi pada anak remaja di Nusa Tenggara Barat (NTB), relatif tingginya angka perceraian orang tua dan banyaknya jumlah anak hidup bersama orang tua tiri.

Di Nusa Tenggara Barat tahun 2007 sebanyak 1.700 kasus perceraian dan tahun 2008 terjadi 2.251 kasus meningkat menjadi 3.231 kasus perceraian tahun 2009. Sedangkan keterpaparan materi pornografi dan perilaku seksual siswa sekolah menengah pertama negeri diperoleh data sekitar 91\% 
siswa SMP negeri di Kota Mataram telah terpapar materi pornografi. Kondisi ini akan semakin rumit jika komunikasi dalam keluarga tentang seksual tidak berjalan baik.

Terkait dengan kondisi tersebut, maka dipandang perlu untuk melakukan penelitian tentang "hubungan perilaku seksual remaja SMU dengan status pernikahan orang tua di Kota Mataram"

\section{METODE PENELITIAN}

Penelitian ini merupakan penelitian observasional, menggunakan desain cross-sectional.Penelitian ini dilakukan di SMU yang ada di Kota Mataram.Populasi merupakan keseluruhan sumber data yang diperlukan dalam suatu penelitian. Populasi target penelitiannya adalah siswa SMA 3 Mataram, SMA 45 Mataram, SMA Alma'arif Mataram dan siswa SMA NW Mataram. Dengan kriteria inklusi adalah remaja laki-laki maupun perempuan yang orang tuanya bercerai (bercerai hidup) atau tidak bercerai (orang tua lengkap) dan berusia antara 15-19 tahun. Kriteria eksklusi sebagai berikut: remaja orang tuanya bercerai mati maupun remaja kedua orang tuanya meninggal dunia.

Perkiraan besar sampel ditetapkan menggunakan rumus Hypotheses Tests for Two Population Proportion (two-sided test).

$$
n=\frac{\left\{Z_{1-\alpha / 2} \sqrt{2 \overline{\mathrm{P}}(1-\overline{\mathrm{P}})}+Z_{1-\beta} \sqrt{\mathrm{P}_{1}\left(1-\mathrm{P}_{1}\right)+\mathrm{P}_{2}\left(1-\mathrm{P}_{2}\right)}\right\}^{2}}{\left(\mathrm{P}_{1}-\mathrm{P}_{2}\right)^{2}}
$$

Keterangan:

$Z_{1-\alpha}: 1,96(\alpha=0,05$ dengan tingkat kepercayaan 95\%)

$1-\beta \quad$ : Power of the test (90\%)

P1 : Proporsi remaja perilaku seksual tinggi dengan status keluarga orang tua lengkap $(0,44)$.

P2 : Proporsi remaja perilaku seksual tinggi dengan status keluarga tidak lengkap/bercerai $(0,33)$. 
Berdasarkan perhitungan besar sampel di atas, maka jumlah sampel untuk penelitian ini adalah 410.Untuk mengantisipasi terjadinya missing data, maka sampel ditambah 10\% menjadi 451 siswa.

Total sampel sebanyak 451 siswa. Sampel penelitian ini diambil dengan teknik purposive sampling/judgmental sampling terhadap remaja SMU di Kota Mataram. Dalam pengambilan subjek penelitian di sekolah, dilakukan dengan teknik cluster random sampling.

Variabel penelitian ini meliputi: variabel independen (bebas): status pernikahan orang tua, dependen (terikat): perilaku seksual pada remaja, dan variabel luar: pendidikan orang tua (ayah), pengaruh teman sebaya, dan keterpaparan media massa. Sumber data yang digunakan dalam penelitian ini adalah: data primer dan sekunder. Instrumen digunakan dalam penelitian ini adalah kuesioner.Kuesioner dalam penelitian ini adalah kuesioner tertutup dengan bentuk memilih jawaban.Kuesioner diadopsi dari SKRRI 2007.

Analisis data penelitian dilakukan dengan tahap-tahap sebagai berikut: analisis univariabel, bivariabel, dan multivariabel. Uji statistik chi square $\left(\chi^{2}\right)$ dan regresi logistik dengan tingkat kemaknaan $\mathrm{p}<0.05$ dengan Rasio prevalensi(RP) dengan IK 95\%.

\section{HASIL DAN PEMBAHASAN}

\section{Karakteristik Subjek Penelitian}

Gambaran subjek penelitian berdasarkan jenis kelamin, remaja laki-laki sebesar 50,3\%, dapat dikatakan bahwa karakteristik responden berdasarkan jenis kelamin seimbang dengan sex ratio 1,01. Hasil penelitian menunjukkan usia responden terbanyak $\leq 16$ tahun $(61,6 \%)$ dengan range usia antara 15-19 tahun. 
MUKMINAH, DKK.

Tabel 1

Distribusi Frekuensi Karakteristik Responden Penelitian

\begin{tabular}{|l|c|c|}
\hline \multicolumn{1}{|c|}{ Karakteristik Responden } & n & \% \\
\hline Jenis Kelamin & & \\
Laki-laki & 227 & 50,3 \\
Perempuan & 224 & 49,7 \\
\hline Usia & & \\
$\leq 16$ thn & 215 & 61,6 \\
17 thn & 144 & 31,9 \\
$\geq 18$ thn & 29 & 6,4 \\
\hline Anak ke- & & \\
1 & 186 & 41,2 \\
2 & 134 & 29,7 \\
$\geq 3$ & 131 & 29,1 \\
\hline Jumlah saudara (laki-laki dan perempuan) & & \\
Tanpa saudara (anak tunggal) & 12 & 2,7 \\
1 saudara & 104 & 23,1 \\
2 saudara & 153 & 33,9 \\
$\geq 3$ saudara & 182 & 40,4 \\
\hline Status kebersamaan dengan orang tua & & \\
Ayah dan ibu kandung & 294 & 65,2 \\
Ayah /ibu saja & 67 & 14,9 \\
Ayah/ibu tiri & 65 & 14,4 \\
Orang tua angkat/lainnya & 25 & 5,6 \\
\hline
\end{tabular}

Keterangan: $\mathrm{n}=$ Jumlah sampel

Dilihat dari urutan anak dalam keluarga, 41,2\% sebagai anak sulung. Responden sebagai anak ke kedua, ketiga dan seterusnya $58,8 \%$. Berdasarkan jumlah saudara, 2,7\% responden anak tunggal (tanpa saudara), 23,1\% mempunyai 1 saudara, 74,3\% lebih dari 1 saudara. Untuk status kebersamaan tempat tinggal dengan orang tua didapatkan $65,2 \%$ tinggal dengan ayah dan ibu kandung, $14,9 \%$ tinggal dengan ayah/ibu saja, $14,4 \%$ tinggal dengan ayah/ibu tiri, dan 5,6\% tinggal dengan orang tua angkat/anggota keluarga yang lain.

46 BIOTA: Jurnal Tadris IPA Biologi FITK IAIN Mataram 


\section{Analisis Deskriftif}

a. Perilaku seksual pada remaja SMU

Berdasarkan hasil penelitian perilaku seksual remaja SMA di Kota Mataram, diperoleh persentase perilaku yang masuk dalam kategori perilaku seksual berat.Persentase perilaku seksual berat pada remaja (Meraba, Petting dan intercourse) dapat dilihat pada gambar berikut.

\section{Persentase Perilaku Seksual Remaja}

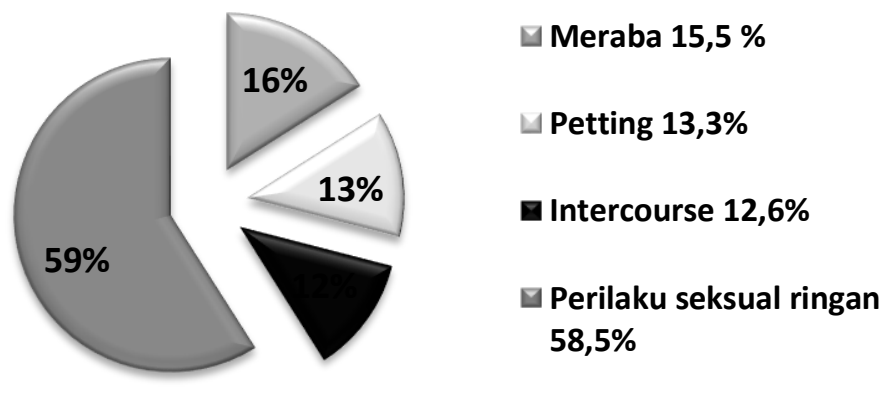

\section{Gambar 1}

Persentase perilaku seksual pada remaja

Jika melihat Gambar 1, pada kategori perilaku seksual berat, 70 remaja sudah pernah meraba/diraba bagian tubuh sensitif, 60 remaja sudah melakukan petting (menggesek/menempelkan alat kelamin pada alat kelamin pasangan), 57 remaja mengaku pernah melakukan hubungan seksual (intercourse). Berdasarkan Gambar 1, hampir setengah dari total responden pernah melakukan perilaku seksual berat 41\% (187 remaja) dan sisanya 59\% berperilaku seksual ringan. 
b. Status pernikahan orang tua

Dalam penelitian ini, variabel status pernikahan orang tua dikategorikan menjadi dua yakni orang tua bercerai (hanya yang bercerai hidup) dan orang tua lengkap.Distribusi frekuensi status pernikahan orang tua responden pada penelitian ini dapat dilihat pada Gambar 2 di bawah ini.

\section{Status Pernikahan Orang Tua}

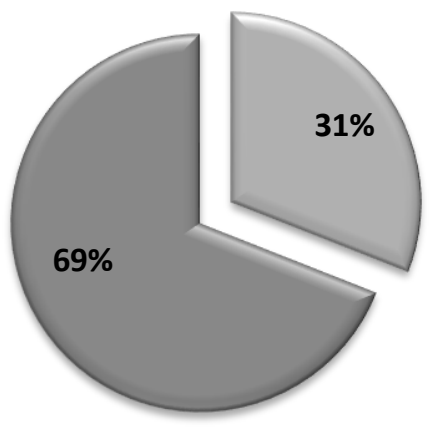

$\square$ Orang tua bercerai $30,8 \%$

$\square$ Orang tua lengkap

$69,2 \%$

\section{Gambar 2}

Distribusi frekuensi status pernikahan orang tua

Pada Gambar 7 menunjukkan bahwa kategori status orang tua bercerai sebanyak 139 orang tua atau 30,8\%. Untuk kategori orang tua lengkap 312 orang tua atau $69,2 \%$ (orang tua responden masih berstatus suami istri pada saat penelitian dilakukan).

c. Pendidikan orang tua, pengaruh teman sebaya dan paparan media massa

Tabel 2, menunjukkan $75 \%$ pendidikan orang tua (ayah) responden kategori "tinggi" (orang tua responden pernah menamatkan pendidikan $\geq$ SLTA/SMA). Responden dengan ayah berpendidikan SLTA/SMA 174 orang atau $38,5 \%$, diploma 23 orang atau $5,1 \%$ dan S1 dan seterusnya 
139 orang atau 30,8\%. Sisanya orang tua (ayah) dengan pendidikan rendah $25,7 \%$ (116 orang).

\section{Tabel 2}

Distribusi frekuensi responden untuk variabel Pendidikan Orang Tua, Pengaruh Teman Sebaya dan Paparan Media Massa

\begin{tabular}{|l|c|c|}
\hline \multicolumn{1}{|c|}{ Variabel Penelitian } & Frekuensi (n= 451) & \% \\
\hline Pendidikan ayah & 335 & \\
Tinggi & 116 & 74,3 \\
Rendah & & 25,7 \\
\hline Pengaruh teman sebaya & 195 & \\
Tinggi & 256 & 43,2 \\
Rendah & & 56,8 \\
\hline Paparan media massa & 336 & \\
Terpapar & 115 & 74,5 \\
Tidak terpapar & & 25,5 \\
\hline
\end{tabular}

$\mathrm{n}=$ Jumlah sampel

Pada variabel pengaruh teman sebaya, kategori pengaruh teman sebaya "tinggi" dengan proporsi $43,2 \%$ dan $56,8 \%$ untuk kategori pengaruh teman sebaya "rendah". Variabel paparan media massa, pada kategori "terpapar" dengan proporsi $74,5 \%$ dan pada ketegori "tidak terpapar" dengan proporsi 25,5\%.

\section{Hubungan Perilaku Seksual pada Remaja SMU dengan Status Pernikahan Orang Tua}

a. Hubungan status pernikahan orang tua dengan perilaku seksual pada remaja SMU

Analisis bivariabel dilakukan guna melihat hubungan antara variabel bebas dengan variabel terikat. Dalam analisis ini digunakan uji statistik Chi-Square $\left(\chi^{2}\right)$ dengan $\alpha$ 0,05 dan Rasio Prevalensi (RP) dengan Interval Konfidensi (IK) 95\%. 


\section{Tabel 3}

Hubungan status pernikahan orang tua dengan perilaku seksual pada remaja

\begin{tabular}{|c|c|c|c|c|c|c|c|c|}
\hline \multirow{3}{*}{$\begin{array}{l}\text { Status } \\
\text { pernikahan } \\
\text { orang tua }\end{array}$} & \multicolumn{4}{|c|}{$\begin{array}{c}\text { Perilaku seksual } \\
\text { remaja }\end{array}$} & \multirow{3}{*}{$\chi^{2}$} & \multirow{3}{*}{$p$} & \multirow{3}{*}{$\mathbf{R P}$} & \multirow{3}{*}{$\begin{array}{c}\text { IK } \\
95 \%\end{array}$} \\
\hline & \multicolumn{2}{|c|}{ Berat } & \multicolumn{2}{|c|}{ Ringan } & & & & \\
\hline & $\mathrm{n}$ & $\%$ & n & $\%$ & & & & \\
\hline $\begin{array}{l}\text { Orang tua } \\
\text { bercerai }\end{array}$ & 89 & $\begin{array}{l}64, \\
1\end{array}$ & 50 & 35,9 & $\begin{array}{l}42, \\
1\end{array}$ & $\begin{array}{l}0,0001 \\
*\end{array}$ & $\begin{array}{l}2,0 \\
3\end{array}$ & $\begin{array}{l}1,65- \\
2,50\end{array}$ \\
\hline $\begin{array}{l}\text { Orang tua } \\
\text { lengkap }\end{array}$ & 98 & $\begin{array}{l}31, \\
4\end{array}$ & 214 & 68,6 & & & & \\
\hline
\end{tabular}

Keterangan:

$$
\begin{aligned}
\chi^{2} & =\text { Chi-Square } & & \text { RP }=\text { Rasio Prevalensi } \\
\mathrm{P} & =p \text {-value } & & \text { IK 95\% = Interval Konfidenci 95\% } \\
* & =\text { Signifikan } & &
\end{aligned}
$$

Sesuai dengan hasil analisis pada Tabel 3, menunjukkan bahwa terdapat hubungan yang bermakna secara statistik $(p<0,05)$ antara variabel bebas (status pernikahan orang tua) dengan variabel terikat (perilaku seksual pada remaja) dengan perbandingan prevalensi 2,03 IK 95\% 1,65-2,50. Dengan demikian maka remaja dengan status orang tua bercerai berpeluang untuk berperilaku seksual 2 kali lebih tinggi dibandingkan remaja dengan status pernikahan orang tua lengkap (tidak bercerai.

b. Hubungan antara pendidikan orang tua, pengaruh teman sebaya dan paparan media massa dengan perilaku seksual pada remaja

Berdasarkan hasil analisis pada Tabel 4, untuk variabel pengaruh teman sebaya menunjukkan ada hubungan yang bermakna secara statistik dengan perilaku seksual remaja, dapat dilihat dari nilai $p<0,05$. Remaja yang pengaruh teman sebaya "tinggi" $(62,1 \%)$ berpeluang sebesar 2,4 kali untuk berperilaku seksual berat dibandingkan dengan remaja yang pengaruh teman sebaya 
"rendah" dapat dilihat dari rasio prevalensi 2,4 IK 95\% $(1,90-3,04)$.

\section{Tabel 4}

Hubungan antara pendidikan orang tua, pengaruh teman sebaya dan paparan media massa dengan perilaku seksual pada remaja

\begin{tabular}{|c|c|c|c|c|c|c|c|c|}
\hline \multirow{3}{*}{$\begin{array}{c}\text { Nama } \\
\text { Variabel }\end{array}$} & \multicolumn{4}{|c|}{$\begin{array}{c}\text { Perilaku Seksual } \\
\text { Remaja }\end{array}$} & \multirow{3}{*}{$\chi^{2}$} & \multirow{3}{*}{$p$} & \multirow{3}{*}{ RP } & \multirow{3}{*}{$\begin{array}{l}\text { IK } \\
95 \%\end{array}$} \\
\hline & \multicolumn{2}{|c|}{ Berat } & \multicolumn{2}{|c|}{ Ringan } & & & & \\
\hline & $\mathbf{N}$ & $\%$ & $\mathbf{n}$ & $\%$ & & & & \\
\hline $\begin{array}{l}\text { Pendidikan } \\
\text { ayah }\end{array}$ & & & & & & & & \\
\hline Tinggi & 137 & 40,9 & 198 & 59,1 & 0,17 & 0,67 & 0,94 & $\begin{array}{l}0,74- \\
1,21\end{array}$ \\
\hline Rendah & 50 & 43,1 & 66 & 56,9 & & & & \\
\hline $\begin{array}{l}\text { Pengaruh } \\
\text { teman } \\
\text { sebaya } \\
\text { Tinggi } \\
\text { Rendah }\end{array}$ & $\begin{array}{r}121 \\
66\end{array}$ & $\begin{array}{l}62,1 \\
25,8\end{array}$ & $\begin{array}{r}74 \\
190\end{array}$ & $\begin{array}{l}37,9 \\
74,2\end{array}$ & 59,9 & $0,0001^{*}$ & 2,40 & $\begin{array}{l}1,90- \\
3,04\end{array}$ \\
\hline $\begin{array}{l}\text { Paparan } \\
\text { media } \\
\text { massa } \\
\text { Terpapar } \\
\text { Tidak } \\
\text { terpapar }\end{array}$ & $\begin{array}{r}172 \\
15\end{array}$ & $\begin{array}{l}51,2 \\
13,0\end{array}$ & $\begin{array}{l}164 \\
100\end{array}$ & $\begin{array}{l}48,8 \\
86,9\end{array}$ & 51,37 & $0,0001^{*}$ & 3,92 & $\begin{array}{l}2,42- \\
6,36\end{array}$ \\
\hline
\end{tabular}

Keterangan:

$$
\begin{array}{lll}
x^{2}=\text { Chi-Square } & \text { RP } & =\text { Rasio Prevalensi } \\
\mathrm{P}=p \text {-value } & \text { IK } 95 \%=\text { Interval Konfidensi } 95 \% \\
*=\text { Signifikan } & &
\end{array}
$$

Hasil analisis untuk variabel paparan media massa, berdasarkan uji statistik menunjukkan bahwa paparan media massa memiliki hubungan yang signifikan dengan perilaku seksual pada remaja. Hal ini terlihat dari nilai $p<$ 
0,05 . Berdasarkan nilai rasio prevalensi, remaja dengan kategori terpapar media massa berpeluang hampir 4 kali untuk berperilaku seksual jika dibandingkan dengan remaja yang tidak terpapar media massa dengan nilai rasio prevalensi 3,9 IK 95\% (2,42-6,36).

c. Hubungan antara pendidikan orang tua, pengaruh teman sebaya dan paparan media massa dengan status pernikahan orang tua

Hasil analisis pada Tabel 5 menunjukkan tidak ada hubungan yang bermakna antara variabel luar (pendidikan orang tua, pengaruh teman sebaya dan paparan media massa) dengan variabel bebas (status pernikahan orang tua). dengan demikian variabel luar bukan sebagai confounding hanya sebagai efek modifikasi (effect modification).

\section{Tabel 5}

Hubungan antara pendidikan orang tua, pengaruh teman sebaya dan paparan media massa dengan status pernikahan orang tua

\begin{tabular}{|c|c|c|c|c|c|c|c|c|}
\hline \multirow{3}{*}{$\begin{array}{c}\text { Nama } \\
\text { Variabel }\end{array}$} & \multicolumn{4}{|c|}{$\begin{array}{c}\text { Status Pernikahan Orang } \\
\text { Tua }\end{array}$} & \multirow{3}{*}{$\chi^{2}$} & \multirow{3}{*}{$\mathbf{p}$} & \multirow{3}{*}{ RP } & \multirow{3}{*}{$\begin{array}{l}\text { IK } \\
95 \%\end{array}$} \\
\hline & \multicolumn{2}{|c|}{ Bercerai } & \multicolumn{2}{|c|}{ Lengkap } & & & & \\
\hline & $\mathbf{N}$ & $\%$ & $\mathbf{N}$ & $\%$ & & & & \\
\hline $\begin{array}{l}\text { Pendidikan } \\
\text { ayah }\end{array}$ & & & & & & & & \\
\hline Tinggi & 102 & 30,4 & 233 & 69,6 & 0,08 & 0,77 & 0,95 & $\begin{array}{l}0,69- \\
1,30\end{array}$ \\
\hline Rendah & 37 & 31,9 & 79 & 68,1 & & & & \\
\hline $\begin{array}{l}\text { Pengaruh } \\
\text { teman sebaya } \\
\text { Tinggi } \\
\text { Rendah } \\
\end{array}$ & $\begin{array}{l}69 \\
70 \\
\end{array}$ & $\begin{array}{l}35,4 \\
27,3 \\
\end{array}$ & $\begin{array}{l}126 \\
186 \\
\end{array}$ & $\begin{array}{l}64,6 \\
72,7\end{array}$ & 3,36 & 0,06 & 1,29 & $\begin{array}{l}0,98- \\
1,70\end{array}$ \\
\hline $\begin{array}{l}\text { Paparan } \\
\text { media massa } \\
\text { Terpapar } \\
\text { Tidak } \\
\text { terpapar }\end{array}$ & $\begin{array}{r}111 \\
28\end{array}$ & $\begin{array}{l}33,0 \\
24,4\end{array}$ & $\begin{array}{r}225 \\
87\end{array}$ & $\begin{array}{l}66,9 \\
75,7\end{array}$ & 3,03 & 0,08 & 1,35 & $\begin{array}{l}0,95- \\
1,93\end{array}$ \\
\hline
\end{tabular}


Keterangan:

$$
\begin{array}{ll}
\chi^{2}=\text { Chi-Square } & \mathrm{RP}=\text { Rasio Prevalensi } \\
\mathrm{P}=p \text {-value } & \text { IK 95\% }=\text { Interval Konfidensi } 95 \%
\end{array}
$$

Secara keseluruhan dapat disimpulkan bahwa dari ketiga variabel luar yang dianalisis, tidak ada yang berhubungan dengan variabel bebas (status pernikahan orang tua). Pada analisis variabel luar dengan variabel terikat, terdapat 2 variabel luar yang berhubungan dengan variabel terikat, yakni pengaruh teman sebaya dan paparan media massa.

\section{PEMBAHASAN}

Hasil penelitan menunjukkan bahwa remaja dengan orang tua bercerai berperilaku seksual lebih tinggi dibandingkan remaja dengan status orang tua lengkap. Dengan demikian terdapat hubungan yang bermakna secara statistik antara variabel bebas (status pernikahan orang tua) dengan variabel terikat (perilaku seksual pada remaja). Status pernikahan orang tua "bercerai" berpeluang meningkatkan perilaku seksual pada remaja 2 kali lebih tinggi dibandingkan remaja dengan status pernikahan orang tua "lengkap" (tidak bercerai).

Masalah perceraian di Nusa Tenggara Barat khususnya di Pulau Lombok seakan sudah menjadi tradisi yang biasa di kalangan masyarakat. Memiliki orang tua tiri atau saudara tiri sudah lumrah di kalangan remaja Pulau Lombok. Banyak faktor yang membuat tradisi kawin cerai di Pulau Lombok seperti yang disebutkan oleh Wahyudi (2004), bahwa perceraian di Pulau Lombok disebabkan oleh faktor-faktor berikut antara lain: faktor ekonomi, faktor kebudayaan masyarakat, faktor kawin muda, faktor agama dan faktor pendidikan. Hal senada juga diungkapkan oleh Watoni (2008), bahwa ada dua faktor utama yang menjadi pemicu banyaknya kasus perceraian yakni faktor ekonomi dan sosial budaya atau tradisi yang hidup yang berkembang di masyarakat. Masalah kawin cerai ini menimbulkan berbagai 
permasalahan pada orang tua maupun anak yang menjadi korban orang tua yang bercerai.

Beberapa perilaku yang masuk dalam kategori perilaku seksual ringan dalam penelitian ini antara lain: pernah tertarik pada lawan jenis, pernah kencan walaupun hanya 1 kali, kencan di tempat sepi atau pribadi, pernah ciuman singkat/ciuman basah. Untuk perilaku seksual berat, ada beberapa perilaku yakni pernah meraba/diraba payudara, pernah meraba/diraba penis atau vagina oleh pacar, pernah melakukan oral sex, dan pernah melakukan hubungan intim (intercourse) (L'Engle et al., 2006).

Hasil penelitian ini sejalan dengan penelitian terhadap faktor-faktor yang berhubungan dengan perilaku seksual murid SMU Negeri di Kota Padang. Penelitian ini memperlihatkan bahwa responden dengan struktur keluarga tidak lengkap mempunyai peluang 3,75 kali untuk berperilaku seksual berisiko berat dibandingkan dengan struktur keluarga lengkap. Secara teoritis keutuhan keluarga berpengaruh terhadap perilaku remaja. Seorang ayah akan menjadi panutan bagi remaja laki-laki dan ibu menjadi panutan bagi remaja puteri. Perilaku orang tua merupakan contoh bagi anaknya, dan umumnya remaja yang bermasalah berasal dari keluarga yang tidak utuh (Nursal, 2008).

Santrock dalam bukunya adolescent perkembangan remaja, menyebutkan bahwa remaja yang dewasa terlalu dini dan berasal dari keluarga yang bercerai sering terlibat konflik dengan ibunya, berperilaku tidak patuh, memiliki harga diri yang lebih rendah dan sering mengalami masalah dalam hubungannya dengan lawan jenis. Selanjutnya didapatkan bahwa perceraian juga mempengaruhi perilaku heteroseksual remaja puteri. Dalam sebuah penelitian yang dilakukan oleh Mavis Hetherington, menunjukkan bahwa remaja yang tidak mempunyai ayah biasanya berperilaku dengan salah salah satu cara yang ekstrim terhadap laki-laki (mereka sangat menarik diri, pasif dan minder atau malah sebaliknya terlalu aktif, agresif dan genit). Beberapa Penelitian menyebutkan bahwa faktor keluarga berpengaruh terhadap kejadian perilaku seksual risiko berat pada remaja.Guijarro dan kawan-kawan meneliti hubungan antara karakteristik keluarga dengan kejadian kehamilan pada remaja di

54 BIOTA: Jurnal Tadris IPA Biologi FITK IAIN Mataram 
Quito Ecuador.Pada penelitiannya Guijarro menemukan bahwa orang tua yang bercerai dan komunikasi buruk antara orang tua dan anak (remaja) berhubungan dengan kejadian kehamilan remaja.

Quinlan melakukan studi perkembangan reproduksi pada 10.847 remaja perempuan di Amerika Serikat.Hasilnya mengindikasikan bahwa waktu perceraian orang tua berhubungan dengan perkembangan reproduksi. Percerain orang tua ketika anak lahir sampai usia 5 tahun, diprediksikan akan menimbulkan menarche yang lebih awal, hubungan seksual pertama, kehamilan pertama, dan pendeknya durasi pernikahan pertama. Remaja dengan orang tua bercerai akan mempunyai beberapa pasangan seksual. Hal serupa juga didapatkan oleh Lee yang meneliti faktor risiko kejadian kehamilan pada remaja dengan konteks keluarga. Faktor keluarga yang dimaksudkan dalam penelitian ini, termasuk di dalamnya yaitu remaja yang hidup jauh dari orang tua, remaja dengan orang tua tunggal, disfungsi keluarga, pendidikan ibu yang rendah serta ibu yang menjadi orang tua pada saat masih remaja merupakan faktor yang signifikan terhadap kejadian kehamilan pada remaja. Penelitian Peres terhadap remaja usia 13-24 tahun di Brazil menemukan bahwa tingkat perilaku berisiko remaja, termasuk keterlibatan remaja dalam hal kriminal, kekerasan, penggunaan obat-obatan dan alkohol serta seksual berisiko, perbandingannya yakni pada remaja yang hidup dengan kedua orang tua tingkat perilaku berisikonya paling rendah, remaja dengan single parent tingkat perilaku berisikonya tinggi dan yang paling tinggi tingkat perilaku berisiko pada remaja yang tinggal dengan selain orang tua. Perbandingan persentase remaja dengan perilaku seksual aktif, $26 \%$ hidup dengan kedua orang tua, 37\% hidup dengan satu orang tua, dan $71 \%$ hidup dengan selain orang tua.

Berdasarkan analisa WHO pada berbagai literatur kesehatan reproduksi dari seluruh dunia menyatakan bahwa pola asuh merupakan faktor risiko perilaku seksual risiko berat.Berbagai interaksi antara remaja dan orang tua dapat menunda bahkan mengurangi perilaku hubungan seksual pada remaja. Tidak adanya pengawasan dari orang tua akan mempercepat seorang 
remaja untuk melakukan hubungan seksual. Remaja yang diawasi oleh orang tuanya, remaja dengan pola asuh otoriter, remaja yang berasal dari keluarga yang konservatif serta memegang kuat tradisi dan memiliki hubungan akrab dengan orang tuanya akan menunda umur pertama melakukan hubungan seksual. Pengawasan orang tua merupakan faktor penting yang mempengaruhi perilaku seksual remaja. Remaja yang diawasi orang tuanya akan menunda bahkan menghindari hubungan seksual sedangkan pada remaja tanpa pengawasan orang tua akan melakukan hubungan seksual pertama pada usia lebih dini. Semua faktor di atas, komunikasi dengan orang tua, pengawasan orang tua, pola asuh, serta keakraban dan keharmonisan yang diberikan orang tua tidak aka nada pada anak dengan status orang tua bercerai. Oleh karena itu, semua faktor tersebut akan berawal dari keluarga lengkap/ keluarga yang utuh.

Orang tua harus dapat menyediakan waktu yang cukup untuk berinteraksi dan berkomunikasi secara terbuka mengenai masalah seksual dengan remaja di rumah, dan berbicara apa saja mengenai kehidupan yang berhubungan dengan remaja, serta dapat menjadi teman yang baik bagi remaja. Oleh sebab itu, benteng yang paling kuat adalah menciptakan keluarga yang harmonis dan komunikasi antara remaja dan orang tua dituntut lancar dan berkualitas. Komunikasi antara anggota keluarga dilandasi oleh adanya saling perhatian, saling menghargai satu sama lain. Pada akhirnya remaja dapat terhindar dari perilaku yang berisiko seperti aktivitas seksual, obat - obat terlarang dan kenakalan remaja lainnya.

Pada penelitian ini, pendidikan orang tua dinyatakan tidak bermakna secara statistik terhadap perilaku seksual pada remaja SMU. Beberapa penelitian menemukan adanya hubungan yang signifikan antara perilaku seksual remaja dengan tingkat pendidikan orang tua.Pendidikan orang tua memiliki hubungan yang sangat kuat dengan kejadian remaja yang melakukan hubungan seksual (intercourse). Hal tersebut diperparah lagi dengan pandangan orang tua bahwa masalah seksual merupakan masalah yang tabu untuk dibicarakan ataupun didiskusikan dalam keluarga. 
Pendidikan ayah responden rata-rata kategori "tinggi" (pernah menamatkan sekolah menengah atas dan seterusnya), namun karena faktor atau alasan-alasan tersebut, maka ayah atau orang tua tidak bisa berdiskusi masalah seksual dengan anak remaja mereka.Hal ini yang menjadi salah satu faktor yang menyebabkan orang tua tidak merasa nyaman atau merasa tidak memiliki pengetahuan yang cukup mengenai topik seksualitas untuk dijelaskan kepada putra putrinya.Pada umumnya responden tidak pernah membicarakan masalah seksual dengan orang tua, karena hal tersebut dianggap tabu/ tidak sopan. Adanya perasaan tidak nyaman dan anggapan tabu dari responden serta orang tua sering di luar rumah, orang tua merasa tidak memiliki pengetahuan cukup tentang masalah seksualitas, akhirnya penjelasan dari orang tua tidak didapatkan oleh remaja.

Remaja dengan pengaruh teman sebaya "tinggi" berpeluang sebesar 2,4 kali untuk berperilaku seksual berat dibandingkan remaja dengan pengaruh teman sebaya "rendah". Teman sebaya memberikan dukungan terhadap perilaku romantis serta dalam membuat keputusan masalah seksualitas.

Hampir 65\% responden mengaku mendapat tekanan serta kehilangan support atau dukungan dari teman mereka, jika mereka memutuskan untuk tidak melakukan seks.Sebagaian remaja menganggap bahwa teman adalah sumber informasi yang penting.Jika pengetahuan teman sebaya tidak memadai mengenai kesehatan seksual, maka remaja bisa mendapatkan informasi yang salah.

Paparan media massa memiliki hubungan yang signifikan dengan perilaku seksual remaja. Remaja dengan kategori "terpapar" media massa berpeluang hampir 4 kali lebih tinggi untuk berperilaku seksual dibandingkan dengan remaja yang tidak terpapar media massa.

Hasil penelitian ini sejalan dengan penelitian Brown et al., dimana remaja juga menganggap bahwa media massa sebagai pemberi informasi yang hebat (super peer) khususnya dalam masalah seksual. Pengaruh media massa bagi remaja memang 
tidak dapat dihindari lagi, apalagi remaja sudah terpapar sexual explicit web sites (SEW).

Dalam penelitian yang lain disebutkan bahwa media massa sebagai media informasi selain mengandung nilai manfaat/positif, terkadang secara tidak sengaja menjadi media yang sangat ampuh dalam memberikan informasi yang negatif seperti informasi seksual yang tidak pantas bagi remaja.

Jika melihat kondisi ini, idealnya para orang tua selalu menjadi pendamping anak-anak dan remaja dalam memberikan penjelasan mengenai adegan atau peristiwa dalam tayangantayangan yang berbau pornografi dalam media massa. Menjadi teman yang akan memberikan mereka penjelasan dan menanamkan rasa tanggung jawab terhadap diri mereka bahwa ada hal-hal yang patut dan tidak patut mereka lakukan. Menjelaskan bahwa informasi yang mereka dapatkan dari media harus difilter, ada yang boleh ditiru dan ada yang tidak boleh ditiru.

\section{PENUTUP}

\section{Kesimpulan}

Berdasarkan hasil temuan dalam penelitian dan analisis data serta pembahasan, maka dapat diambil kesimpulan sebagai berikut: Peluang terjadinya perilaku seksual pada remaja dengan status orang tua bercerai 2 kali lebih tinggi dibandingkan remaja dengan status orang tua tidak bercerai (lengkap). Pengaruh teman sebaya serta keterpaparan remaja dengan media massa memiliki hubungan yang signifikan dengan perilaku seksual. Remaja dengan status orang tua bercerai, pengaruh teman sebaya tinggi serta terpapar media massa, berpeluang 4 kali lebih tinggi untuk berperilaku seksual dibandingkan remaja dengan status orang tua tidak bercerai. 


\section{DAFTAR PUSTAKA}

Anonim. Tahun 2009 Terjadi Perceraian 3.231 Perceraian di NTB. 2010: Available from:

Azwar S. 2011. Metode Penelitian,Yogyakarta: Pustaka Pelajar.

Badan Pusat Statistik, Macro I. 2008. Indonesia Young Adult Reproductive Health Surpey 2007. Calverton, Maryland. USA: BPS And Macro International.

Braun-Courville DK, Rojas M. Exposure to Sexually Explicit Web Site and Adolescent Sexual Attitudes and Behaviors. Journal of Adolescent Health. 2009;45:156-62.

Brown JD, Halpern CT, L' Engle Kelly Ladin. Mass Media as a Sexual Super Peer for Early Maturing Girls. Journal Of Adolescent Health. 2005;36:420-7.

Dinkes NTB. Profil Kesehatan Propinsi Nusa Tenggara Barat Tahun 2007. Mataram 2007: available from: http://www.depkes.go.id/downloads/profil/prov20ntb\%2 02007.pdf.

Guijarro S, et al. Family Risk Factors Associated With Adolescent Pregnancy. Journal of Adolescent Health. 1999;25:166-72.

Jaccard J, et al. Maternal Discussions About Pregnancy and Adolescents, Attitudes Toward Pregnancy. Journal of Adolescent Health. 2003;33:84-7.

Jones RK, et al. Religious Differentials in the Sexual and Reproductive Behaviors of Young Women in the United States. Journal of Adolescent Health. 2005;36:279-88.

Kaye K, et al. Marital Quality and Parent-Adolescent Relatoinships: Effects on Sexual Activity Among Adolescent and Young Adults. 2008.

Lee M-C, et al. Family and Adolescent Childbearing. Journal of Adolescent Health. 2001;28:307-12.

Lemeshow S, et al. 1997. Besar Sampel Dalam Penelitian Kesehatan, Yogyakarta: Gadjah Mada University Press.

L'Engle KL, et al. The Mass Media are an Importance Contex For Adolescents Sexual Behavior. Journal of Adolescent Health. 2006;38:186-92. 
Mariani A, Bachtiar I. Keterpaparan Materi Pornografi dan Perilaku Seksual Siswa Sekolah Menengah Pertama Negeri. Makara, Sosial Humaniora. 2010:14:83-90.

Nursal DGA. Faktor-faktor yang Berhubungan dengan Perilaku Seksual Murid SMU Negeri di Kota Padang Tahun 2007. Jurnal Kesehatan Masyarakat. 2008;II: 175-80.

Okonkwo PI, et al. Perception of Peres Behaviour Regarding Sexual Health Decision Making Among Famale Andergraduates in Anambra State, Nigeria. Afr Health Sci. 2005;5:107-13.

Peres CA, et al. Family Structure and Adolescents Sexual Behavior in a Poor Area of Sao Paulo, Brazil. Journal of Adolescent Health. 2008;42:177-83.

Quinlan RJ. Father Absence, Parental Care and Female Reproductive Development. Evolution and Human Behavior. 2003;24:376-90.

Sacharin RM. 1994. Prinsip Keperawatan Pediatrik (Principles of Paediatric Nursing), Jakarta: Penerbit Buku Kedokteran EGC.

Santelli JS, et al. The association of sexual behavior with socioeconomic status, family structure, Grace/ethnicity among Us Adolescents. Am J Public Health.

Santrock JW. 2003. Adolescence Perkembangan Remaja. Jakarta: Erlangga.

Saryono. 2011. Metodologi Penelitian Kesehatan. Yogyakarata: Mitra Cendikia Press.

Sastroasmoro S, Ismael S. 2008. Dasar-dasar Metodologi Penelitian Klinis. Jakarta: Sagung Seto.

Upadhyay UD. Et al. Do Perception of Friend's Behaviors Affect Age at First Sex Evidence From Cebu, Philippine. Journal of Adolescent Health. 2006;39:570-7.

Wahyudi, H. 2004. Tradisi Kawin Cerai pada Masyarakat Adat Suku Sasak Lombok Serta Akibat Hukum yang Ditimbulkannya. Tesis, Semarang: Program Pascasarjana Universitas Diponegoro.

Watoni, S.A. 2008. Perceraian Akibat Pernikahan Dini (Studi Kasus di Kecamatan Kopang Kab. Lombok Tengah NTB Tahun 2006-2008). Tesis. Yogyakarta: Program Pascasarjana UIN Sunan Kalijaga.

60 BIOTA: Jurnal Tadris IPA Biologi FITK IAIN Mataram 